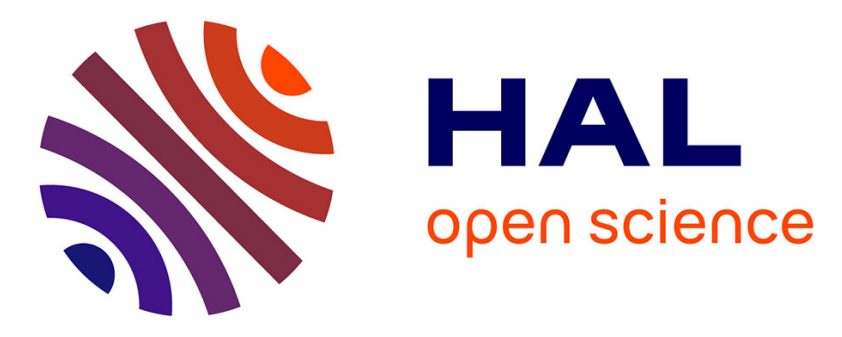

\title{
Palladium-Catalyzed [2+1] Cycloadditions Affording Vinylidenecyclopropanes as Precursors of 7-Membered Carbocycles
}

Aymeric Lepronier, Thierry Achard, Laurent Giordano, Alphonse Tenaglia, Gérard Buono, Hervé Clavier

\section{To cite this version:}

Aymeric Lepronier, Thierry Achard, Laurent Giordano, Alphonse Tenaglia, Gérard Buono, et al.. Palladium-Catalyzed [2+1] Cycloadditions Affording Vinylidenecyclopropanes as Precursors of 7-Membered Carbocycles. Advanced Synthesis and Catalysis, 2016, 358, pp.631 - 642. 10.1002/adsc.201500971 . hal-01409737

\section{HAL Id: hal-01409737 \\ https://hal.science/hal-01409737}

Submitted on 6 Dec 2016

HAL is a multi-disciplinary open access archive for the deposit and dissemination of scientific research documents, whether they are published or not. The documents may come from teaching and research institutions in France or abroad, or from public or private research centers.
L'archive ouverte pluridisciplinaire HAL, est destinée au dépôt et à la diffusion de documents scientifiques de niveau recherche, publiés ou non, émanant des établissements d'enseignement et de recherche français ou étrangers, des laboratoires publics ou privés.

\section{(ㅇ)(1) $\$$}

Distributed under a Creative Commons Attribution - NonCommercial - NoDerivatives 44.0 
DOI: 10.1002/adsc.201((will be filled in by the editorial staff))

\title{
Palladium-catalyzed [2+1] cycloadditions affording vinylidenecyclopropanes as precursors of 7-membered carbocycles
}

\author{
Aymeric Lepronier, ${ }^{\mathrm{a}}$ Thierry Achard, ${ }^{\mathrm{a}, \mathrm{b}}$ Laurent Giordano, ${ }^{\mathrm{a}}$ Alphonse Tenaglia, ${ }^{\mathrm{a}}$ Gérard \\ Buono $^{\mathrm{a}}$ and Hervé Clavier ${ }^{\mathrm{*}}$ *
}

a Aix Marseille Université, Centrale Marseille, CNRS, iSm2 UMR 7313, 13397, Marseille, France phone: (+33) (0)491-288-649; e-mail: hervé.clavier@univ-amu.fr

b Present address: Université de Strasbourg, CNRS, IPCMS UMR 7504, 23, rue du Loess, BP 43, 67034 Strasbourg cedex 2, France

Received:((will be filled in by the editorial staff))

Supporting information for this article is available on the WWW under http://dx.doi.org/10.1002/adsc.201\#\#\#\#\#.((Please delete if not appropriate))

\begin{abstract}
Palladium(II) acetate in association with secondary phosphine oxides provides an efficient catalytic system for $[2+1]$ cycloadditions starting from oxanorbornene derivatives and tertiary propargyl esters giving rise to vinylidenecyclopropanes. This reaction is specific to bidentate phosphinito-phosphinous acid ligands generated from secondary phosphine oxides. The $[2+1]$ cycloaddition was found broad in scope with a high tolerance to various functional groups. Moreover, vinylidenecyclopropanes were
\end{abstract}

straightforwardly converted into oxabicyclo[3.2.1]oct-2-ene derivatives through a palladium-catalyzed ring-expansion. Finally, the oxa bridge cleavage of oxatricyclic compounds allows the obtention of functionalized 7-membered carbocycles.

Keywords:Carbocycles;Cycloaddition; Palladium; Vinylidenecyclopropane; Secondary Phosphine Oxide

\section{Introduction}

The importance of seven-membered rings as ubiquitous structural subunits in natural products and biologically relevant compounds continues to inspire the development of novel methodologies for their preparation. ${ }^{[1]}$ However, due to unfavorable entropic and enthalpic factors, the synthesis of these compounds through ring-closure reactions remains challenging. ${ }^{[2]}$ Among the various synthetic methodologies to prepare cycloheptane derivatives, cycloaddition routes $^{[2,3]}$ such as [4+3] or [5+2] cycloadditions with transition-metal catalysts, ${ }^{[4,5}$ have appeared to be competitive.

As a part of our research program dedicated to the coordination chemistry of secondary phosphine oxides (SPOs) ${ }^{[6]}$ with transition metals ${ }^{[7]}$ and the use of the resulting complexes to develop new synthetic transformations, ${ }^{[8]}$ we reported in 2008 an intriguing vinylidenecyclopropane formation and a ringexpansion giving rise to functionalized bicyclo[3.2.1] octanes (Scheme 1) ${ }^{[9]}$ Palladium(II) complexes bearing a phosphinito-phosphinous acid
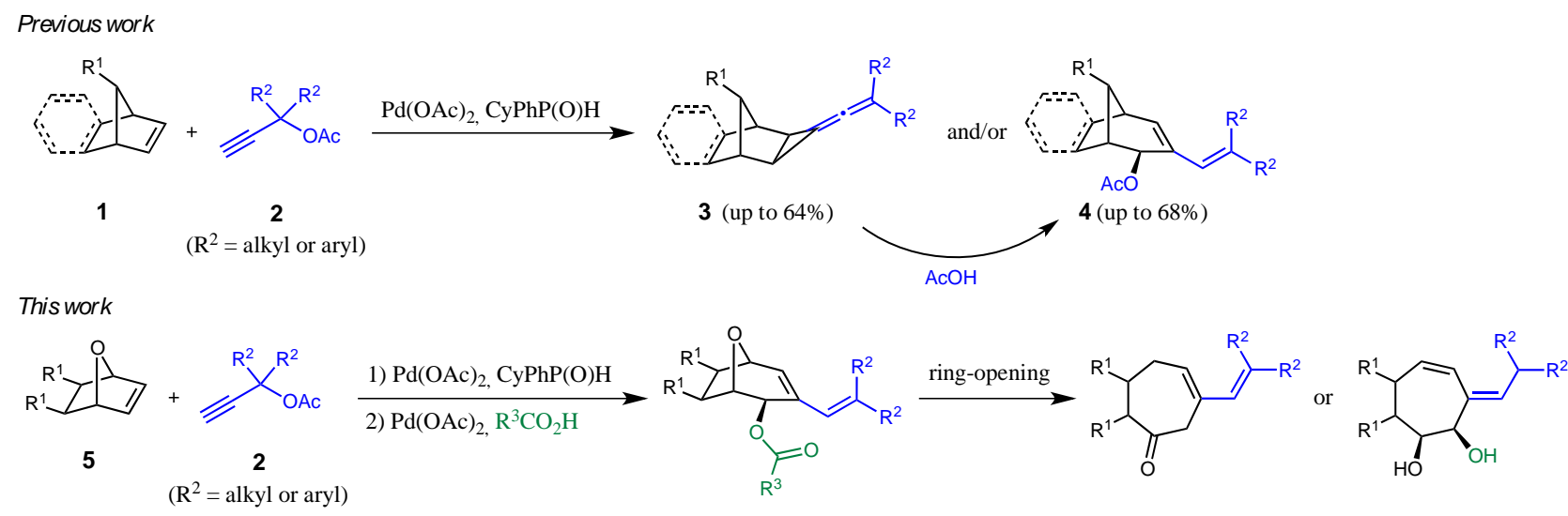

Scheme 1.Palladium-mediated [2+1] Cycloaddition - ring expansion sequences. 
bidentate ligand, generated from SPOs, catalyze $[2+1]$ cycloadditions between strained carbon-carbon double bonds, typically norbornene derivatives $\mathbf{1}$, and terminal alkynes to form methylenecyclopropanes. ${ }^{[8]}$ With tertiary propargyl acetates $\mathbf{2}$, a further reactivity occurred with the release of acetic acid from the adducts and led to the formation of vinylidenecyclopropanes (VDCPs) 3 in up to $64 \%$ yield (Scheme 1). ${ }^{[10]}$ As by-products, bicyclo[3.2.1] octadienes 4 were also produced and, under more drastic reaction conditions, they could be isolated in good yields (up to $68 \%$ yield). Of note, it was demonstrated that VDCPs $\mathbf{3}$ are intermediates in the synthesis of bicyclo[3.2.1]octadienes 4. This is a rare example of cleavage of one $\mathrm{C}-\mathrm{C}$ bond of a bicyclo[4.1.0]heptane unit affording a 7-membered ring, ${ }^{[11]}$ especially starting from VCDPs. ${ }^{[12]}$ Moreover, NMR analyses showed that compounds $\mathbf{4}$ were obtained as a mixture of two diastereomers, with the exo acetoxy group for the major diastereomer. In view of the usefulness of functionalized bicyclo[3.2.1] octane skeletons in modern chemistry ${ }^{[13]}$ this palladium-mediated $[2+1]$ cycloaddition - ring expansion sequence represents a valuable methodology for their preparation.

Nevertheless, oxa-bridged [3.2.1] bicycles have shown a more significant importance in medicinal chemistry $^{[14]}$ such as potency towards HIV-1 inhibition and central nervous system diseases. Moreover, the oxa bridge could operate as temporary tether which after an appropriate carbon-oxygen bond cleavage will release the functionalized 7-membered carbocycle (Scheme 1). ${ }^{[15]}$ Therefore, we decided to study therein, the palladium-catalyzed $[2+1]$

cycloaddition - ring-expansion sequence starting
from oxanorbonene derivatives 5 .

\section{Results and Discussion}

We started by the examination of the palladium-based catalytic system for the [2+1] cycloaddition using tertiary propargyl acetate $\mathbf{2 a}$ and oxanorbornene $\mathbf{5 a}$ as benchmark substrates. As depicted in Table 1, various ligands or preligands, mainly secondary phosphine oxides were screened and only the VDCP 6aa was observed without traces of ring-expanded product 11aa (Table 5). Single-crystal X-ray analysis of 6aa unambiguously confirmed the atom connectivity (Figure 1). Of note, a slight excess of SPOs related to palladium (2.5:1) was used to ensure the formation of the bidentate phosphinito-phophinous acid ligands. With symmetrical SPO preligands, we noticed drastic differences as a function of the nature of substituents on the phosphorus atom (entries 1-4). Whereas $\mathrm{Ph}_{2} \mathrm{P}(\mathrm{O}) \mathrm{H}$ gave $60 \%$ yield of 6aa, other symmetrical SPOs led to up to $10 \%$ yield. In a general manner, dissymmetrical SPOs provides better results with still a sharp contrast as function the P-substituents (entries 5-9). Moderate sterically hindrances of SPO preligands seem to be a key parameter to reach good
Table 1.Ligand screening for the Pd-catalyzed [2+1] cycloaddition. ${ }^{[\mathrm{a}]}$

\begin{tabular}{|c|c|c|}
\hline Entry & Ligand & Yield $(\%)$ \\
\hline 1 & $\mathrm{Ph}_{2} \mathrm{P}(\mathrm{O}) \mathrm{H}$ & 60 \\
\hline 2 & $t \mathrm{Bu}_{2} \mathrm{P}(\mathrm{O}) \mathrm{H}$ & NP \\
\hline 3 & $\mathrm{Cy}_{2} \mathrm{P}(\mathrm{O}) \mathrm{H}$ & 10 \\
\hline 4 & $\mathrm{Me}_{2} \mathrm{P}(\mathrm{O}) \mathrm{H}$ & NP \\
\hline 5 & $\mathrm{Ph} t \mathrm{BuP}(\mathrm{O}) \mathrm{H}$ & 10 \\
\hline 6 & $\mathrm{PhCyP}(\mathrm{O}) \mathrm{H}$ & 76 \\
\hline 7 & $\mathrm{PhBnP}(\mathrm{O}) \mathrm{H}$ & 58 \\
\hline 8 & $\mathrm{Ph} n \mathrm{BuP}(\mathrm{O}) \mathrm{H}$ & 32 \\
\hline 9 & $\mathrm{PhMeP}(\mathrm{O}) \mathrm{H}$ & Complex mixture \\
\hline 10 & None & NP \\
\hline 11 & $\mathrm{PPh}_{3}$ & NP \\
\hline 12 & $\mathrm{P}(\mathrm{OPh})_{3}$ & NP \\
\hline 13 & $\mathrm{Ph}_{2} \mathrm{PO}_{2} \mathrm{H}$ & $\mathrm{NP}$ \\
\hline 14 & $\mathrm{Ph}(\mathrm{OEt}) \mathrm{P}(\mathrm{O}) \mathrm{H}$ & 18 \\
\hline
\end{tabular}

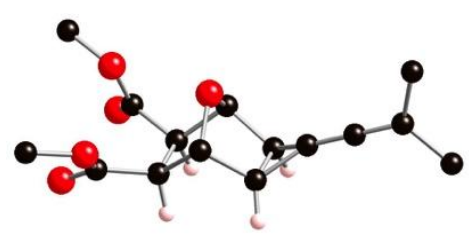

Figure 1.Ball-and-stick representation of compound 6aa (most of hydrogen atoms have been omitted for clarity).

yields in 6aa (entries 6 and 7). Importantly, control experiments without ligand or using triphenylphosphine, triphenylphosphite or phosphinic acid highlighted to crucial role plays by SPOs and precisely by bidentate phosphinito-phophinous acid ligands (entries 10-13). ${ }^{[16]}$ Only with the ethyl phenylphosphinate, we were able to isolate the expected VDCP 6aa in low yield; in this case, it is also possible to generate in situ a phosphinitophophinous acid ligand (entry 14). In order to probe again the specificity of the phosphinito-phophinous acid ligand, it was attempted to mimic it using the 1,3-bis(diphenylphosphino)propane (Scheme 2). Several products were isolated: the Hay-Glaser coupling product 7a in $31 \%$ yield, the enone 8aa in small amount and a vinylcyclopropane 9aa as major product $(44 \%)$ for which the structure has been confirmed by single-crystal X-ray analysis. No VDCP 6aa was detected in the crude mixture.

We then surveyed an array of parameters to identify the optimal reaction conditions for the VDCP formation (Table 2). The use of $\mathrm{Pd}(\mathrm{OTFA})_{2}$ instead of $\mathrm{Pd}(\mathrm{OAc})_{2}$ led to a severe decrease of the reaction yield (entries 1 and 2). Whereas platinum complexes 


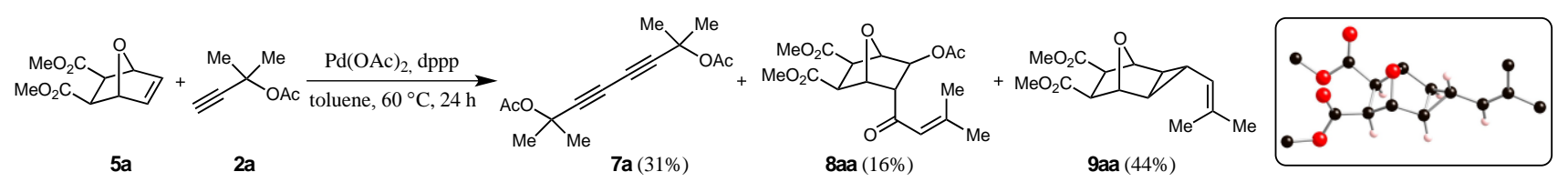

Scheme 2.Control experiment using dppp (1,3-bis(diphenylphosphino)propane) as ligand and ball-and-stick representation of compound 9aa (most of hydrogen atoms have been omitted for clarity).

Table 2.Optimization of the reaction conditions for Pdmediated $[2+1]$ cycloaddition. $^{[\mathrm{a}]}$

\begin{tabular}{|c|c|c|}
\hline $\left.\mathrm{O}_{2} \mathrm{O}_{2} \mathrm{C}\right\rangle$ & 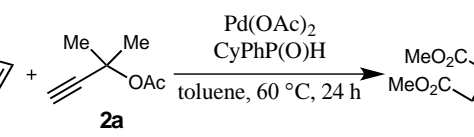 & 6аa \\
\hline Entry & $\begin{array}{l}\text { Change from "standard } \\
\text { conditions" }\end{array}$ & Yield $(\%)$ \\
\hline 1 & none & 76 \\
\hline 2 & $\begin{array}{c}\mathrm{Pd}(\mathrm{OTFA})_{2} \text { instead of } \mathrm{Pd}(\mathrm{OAc})_{2} \\
\mathrm{Pt}(\mathrm{OAc})(\mathrm{PhCyPOHOPPhCy})\end{array}$ & 20 \\
\hline 3 & $\begin{array}{c}\text { instead of } \\
\mathrm{Pd}(\mathrm{OAc})_{2} / \mathrm{PhCyP}(\mathrm{O}) \mathrm{H}\end{array}$ & NP \\
\hline 4 & $25^{\circ} \mathrm{C}$ instead of $60^{\circ} \mathrm{C}$ & 11 \\
\hline 5 & $40^{\circ} \mathrm{C}$ instead of $60^{\circ} \mathrm{C}$ & 41 \\
\hline 6 & $80^{\circ} \mathrm{C}$ instead of $60^{\circ} \mathrm{C}$ & NP \\
\hline 7 & $72 \mathrm{~h}$ instead of $24 \mathrm{~h}$ & 81 \\
\hline 8 & dioxane instead of toluene & 48 \\
\hline 9 & $\mathrm{ClCH}_{2} \mathrm{CH}_{2} \mathrm{Cl}$ instead of toluene & 40 \\
\hline 10 & $\mathrm{MeCN}$ instead of toluene & 34 \\
\hline 11 & DMF instead of toluene & 85 \\
\hline 12 & 1.5 equiv. of $\mathbf{2 a}$ & 51 \\
\hline 13 & 3 equiv. of $\mathbf{2 a}$ & 81 \\
\hline 14 & 5 equiv. of $\mathbf{2 a}$ & $\begin{array}{l}\text { Complex } \\
\text { mixture }\end{array}$ \\
\hline
\end{tabular}

[a] Standard reaction conditions: 5a (1 mmol), 2a (2 $\mathrm{mmol}), \mathrm{Pd}(\mathrm{OAc})_{2}(5 \mathrm{~mol} \%)$, $\mathrm{PhCyP}(\mathrm{O}) \mathrm{H}(12.5 \mathrm{~mol} \%)$, toluene $(5 \mathrm{~mL}, 0.2 \mathrm{M}), 60^{\circ} \mathrm{C}, 24 \mathrm{~h}$. NP $=$ No Product.

bearing a phosphinito-phosphinous acid ligands are efficient catalysts to promote the $[2+1]$ cycloaddition, ${ }^{[8 b]}$ no VDCP could be detected using oxanorbornenes 5 (entry 3). At room temperature or at $40{ }^{\circ} \mathrm{C}$ the VDCP formation occurred slowly and at $80{ }^{\circ} \mathrm{C}$ mainly degradation products were observed (entries 4-6). Increasing the reaction time to 3 days improved slightly 6aa yield (entry 7). The solvents screening revealed that the VDCP formation could be achieved in various solvents, DMF being the most efficient but for practical reasons, toluene was chosen for the rest of our investigations (entries 8-11). Finally, the increase of the alkyne amount to 3 equivalents gave a maximum of $81 \%$ yield in VDCP 6aa (entry 13); with higher quantities of $\mathbf{2 a}$, a complex mixture was obtained (entry 14).

Having established the optimal reaction conditions, we investigated the scope of the catalytic system with a range of alkynes (Table 3). Leaving groups such as benzoate, pivalate or carbonate could be used and similar yields in VDCP 6aa were isolated (entries 24). However, with methoxy- or hydroxy-substituted alkynes, no reaction occurred (entries 5 and 6 ).
Table 3.Pd-mediated vinylidenecyclopropane formation with various alkynes 2 . $^{\text {[a] }}$

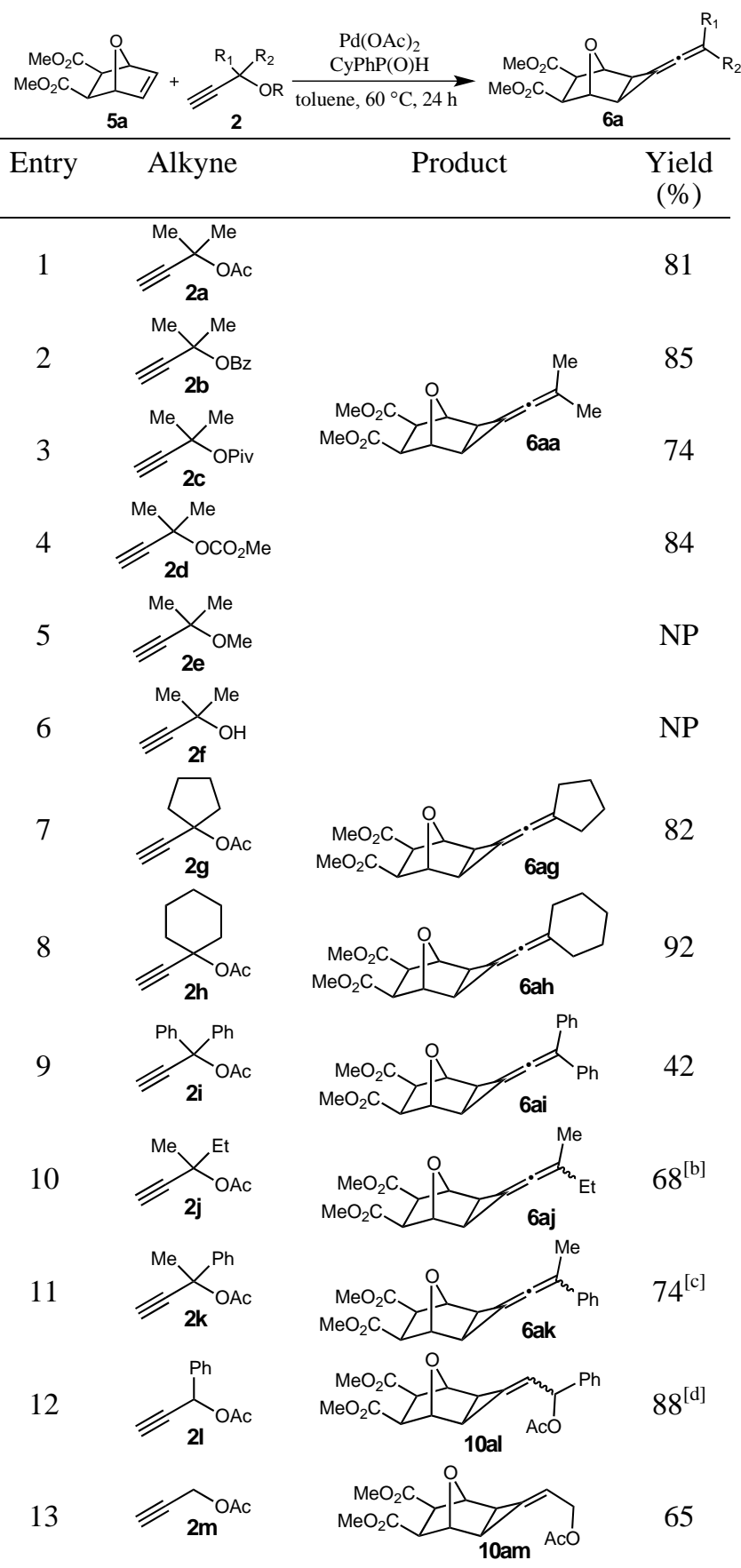

[a] Standard reaction conditions: $5 \mathbf{a}(1 \mathrm{mmol}), 2(3 \mathrm{mmol})$ $\mathrm{Pd}(\mathrm{OAc})_{2}(5 \mathrm{~mol} \%), \mathrm{PhCyP}(\mathrm{O}) \mathrm{H}(12.5 \mathrm{~mol} \%)$, toluene $(5$ $\mathrm{mL}, 0.2 \mathrm{M}), 60^{\circ} \mathrm{C}, 24 \mathrm{~h}$. [b] dr $=1: 1.0$. [c] dr $=1: 1.5$. [d] dr $=1: 1 \cdot 3 . \mathrm{NP}=$ No Product. 
Various tertiary propargyl acetates are also competent (entries7-11) and the best yield was reached with alkyne $\mathbf{2 h}$ (92\%, entry 8). Of note, VDCPs 6aj and 6ak were isolated as an inseparable mixture of diastereomers with a ratio close to 1:1. With secondary and primary propargyl acetates, only methylenecyclopropanes (MCP) 10 were isolated (entries 12 and 13). For MCP 10al, a 1:1.3 mixture of diastereomers was observed due to the geometrical enantiomorphic isomerism (cis-trans enantiomerism or $Z-E$ enantiomerism). ${ }^{[17,18]}$

A wide range of 7-oxanorbornenes 5 were then tested in order to determine the limits of catalytic system (Table 4). The VDCP formation was found compatible with various functional groups such as esters (entry 1), carbonate (entry 2), ethers (entries 4 and 5), silyl ether (entry 6) or even free hydroxyl groups, independently of the endo/exo position of the oxanorbornene substituents (entries 7 and 8). One of the limitations is the competitive retro Diels-Alder reaction of $\mathbf{5 d}$ which is faster than the [2+1] cycloaddition (entry 3 ). This trend was also observed with bis-sulfone $\mathbf{5 j}$ giving rise to VDCP $\mathbf{6 j a}$ in only $23 \%$ yield along with the retro D-A product (ca 45\%, entry 9). In this run, dichloroethane was used due to the poor solubility of $\mathbf{6 j}$ in toluene. Similar solubility issues were also encountered with imide derivative 5n (entries 13 and 14). Otherwise, N-containing functional groups such as nitrile (entry 10), carbamate (entry 11) or tertiary amine (entry 12 ) are well tolerated and in a general manner high yields have been obtained.

To fully demonstrate the usefulness on preparative scale, a reaction was performed on 20-mmol scale. As shown in Scheme 3, using $2.5 \mathrm{~mol} \%$ of palladium, it was possible to get up to $5 \mathrm{~g}(93 \%)$ of VDCP 6aa after 3 days at $60{ }^{\circ} \mathrm{C}$. Importantly, VDCPs were found perfectly stable and could be stored for few months at $0{ }^{\circ} \mathrm{C}$.

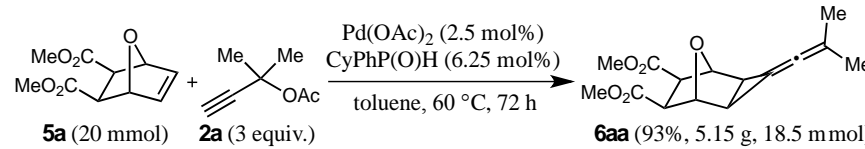

Scheme 3. Multi-gram scale vinylidenecyclopropane synthesis.

The oxabicyclo[3.2.1]oct-2-ene formation from VDCP through a ring-expansion was then examined (Table 5). The treatment of the VDCP 6aa with one equivalent of acetic acid in presence of $5 \mathrm{~mol} \%$ of $\mathrm{Pd}(\mathrm{OAc})_{2}$ gave $84 \%$ of the expected product 11aa (entry 1). ${ }^{[9]}$ Importantly, under these reaction conditions only the exo diastereomer was observed. Its structure was unambiguously determined by single-crystal X-ray analysis (Figure 2). The concentration and the temperature were found to be key parameters to achieve the transformation with high yields (entries 2-4). It was possible to obtain 11aa without $\mathrm{Pd}(\mathrm{OAc})_{2}$, but this required 5 equiv. of $\mathrm{AcOH}$ to isolate a satisfactory yield (entries 5 and 6). Of note, the well-defined palladium complex bearing the phosphinito-phosphinous acid ligand gave product 11aa, but only in low yield (entry 7). The examination of reaction media showed that various solvents could be used; the best yields were reached with toluene and dichloroethane (entries 8-11).

Table 5.Optimization of the reaction condition for the ring-expansion. ${ }^{\text {[a] }}$

\begin{tabular}{|c|c|c|}
\hline & Saa & 11aa \\
\hline Entry & $\begin{array}{l}\text { Change from "standard } \\
\text { conditions" }\end{array}$ & Yield $(\%)$ \\
\hline 1 & None & 84 \\
\hline 2 & $0.2 \mathrm{M}$ instead of $1 \mathrm{M}$ & 43 \\
\hline 3 & $20^{\circ} \mathrm{C}$ instead of $60^{\circ} \mathrm{C}$ & 31 \\
\hline 4 & $40^{\circ} \mathrm{C}$ instead of $60^{\circ} \mathrm{C}$ & 55 \\
\hline 5 & No $\mathrm{Pd}(\mathrm{OAc})_{2}$ & 12 \\
\hline 6 & No $\mathrm{Pd}(\mathrm{OAc})_{2}, 5$ equiv. $\mathrm{AcOH}$ & 69 \\
\hline 7 & $\begin{array}{c}\mathrm{Pd}(\mathrm{OAc})(\mathrm{PhCyPOHOPPhCy})(5 \\
\mathrm{mol} \%) \text {, instead of } \mathrm{Pd}(\mathrm{OAc})_{2}\end{array}$ & 27 \\
\hline 8 & dioxane instead of toluene & 53 \\
\hline 9 & $\mathrm{ClCH}_{2} \mathrm{CH}_{2} \mathrm{Cl}$ instead of toluene & 78 \\
\hline 10 & $\mathrm{MeCN}$ instead of toluene & $54^{[\mathrm{b}]}$ \\
\hline 11 & DMF instead of toluene & 47 \\
\hline
\end{tabular}

[a] Standard reaction conditions: 6aa $(0.5 \mathrm{mmol}), \mathrm{AcOH}$ $(0.5 \mathrm{mmol}), \mathrm{Pd}(\mathrm{OAc})_{2}(5 \mathrm{~mol} \%)$, toluene $(0.5 \mathrm{~mL}, 1 \mathrm{M})$, $60{ }^{\circ} \mathrm{C}, 24 \mathrm{~h}$. [b]exolendo $=3.5: 1$.

Surprisingly, the platinum-based counterpart of phosphinito-phosphinous acid palladium complex was efficient to promote the formation oxabicyclo[3.2.1] oct-2-ene 11, unfortunately as a mixture of exo and endo diastereomers, respectively 11aa and 12aa. The nature of the solvent influenced exolendo ratios but not enough to reach a good diastereoselectivity (Table 6).

Table 6.Optimization of the reaction condition for the ring-expansion. ${ }^{[\mathrm{a}]}$

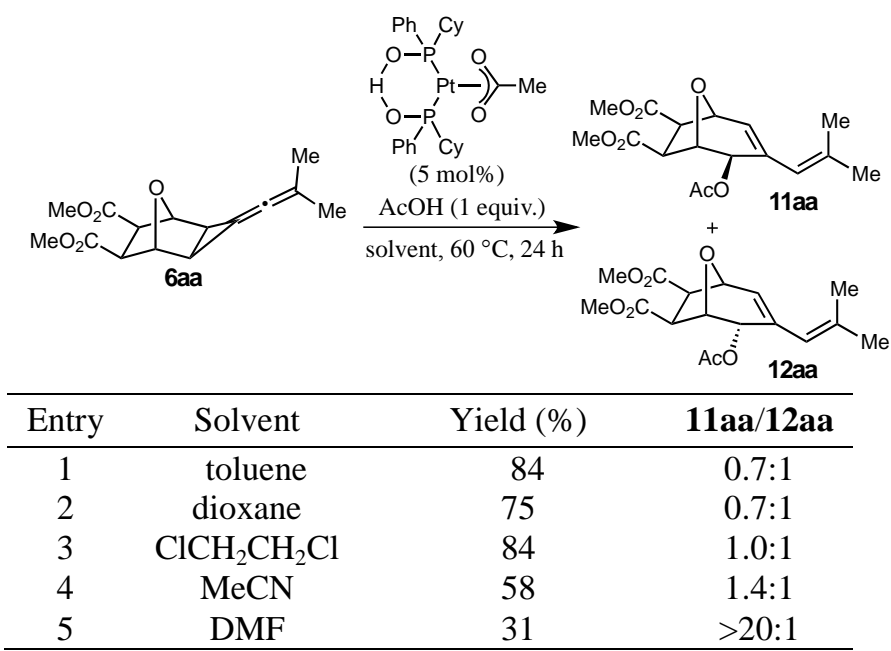

a] Standard reaction conditions: 6aa $(0.5 \mathrm{mmol}), \mathrm{AcOH}$ (0.5 mmol), $\mathrm{Pt}(\mathrm{OAc})(\mathrm{PhCyPOHOPPhCy})$ (5 mol\%), solvent $(2.5 \mathrm{~mL}, 0.2 \mathrm{M}), 60{ }^{\circ} \mathrm{C}, 24 \mathrm{~h} . \mathrm{NP}=$ No Product. 
Table 4.Pd-catalyzed [2+1] cycloaddition with various oxanorbornenes. ${ }^{[a]}$

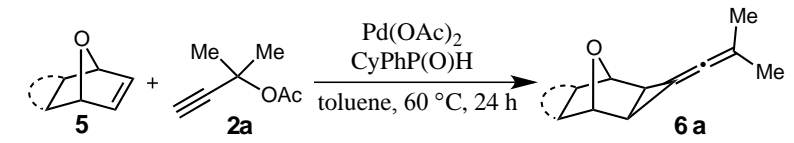

\begin{tabular}{|c|c|c|c|}
\hline Entry & Oxanorbornene & Product & Yield (\%) \\
\hline 1 & & & 80 \\
\hline 2 & & & 77 \\
\hline 3 & & & NP \\
\hline 4 & & & 89 \\
\hline 5 & & & 87 \\
\hline 6 & & & 90 \\
\hline 7 & & & 91 \\
\hline 8 & II & & 76 \\
\hline 9 & & & $23^{[b]}$ \\
\hline 10 & & & 72 \\
\hline 11 & $\begin{array}{r}\mathrm{Me} \\
\mathrm{Me}_{2} \mathrm{I}\end{array}$ & & 95 \\
\hline 12 & & & 96 \\
\hline 13 & & & 58 \\
\hline 14 & & & $77^{[\mathrm{b}]}$ \\
\hline 15 & $\mathrm{AcO}^{\mathrm{AcO}}$ & & NP \\
\hline
\end{tabular}

[a] Standard reaction conditions: 5a $(1 \mathrm{mmol}), 2(3 \mathrm{mmol}), \mathrm{Pd}(\mathrm{OAc})_{2}(5 \mathrm{~mol} \%), \mathrm{PhCyP}(\mathrm{O}) \mathrm{H}(12.5 \mathrm{~mol} \%)$, toluene $(5 \mathrm{~mL}$, $0.2 \mathrm{M}), 60^{\circ} \mathrm{C}, 24 \mathrm{~h} .[\mathrm{b}] \mathrm{dr}=1: 1.0$. [c] dr $=1: 1.5$. [d] $\mathrm{dr}=1: 1.3 . \mathrm{NP}=$ No Product. 


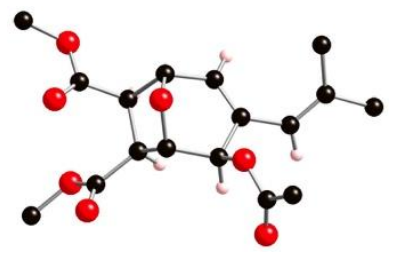

Figure 2. Ball-and-stick representation of compound 11aa (most of hydrogen atoms have been omitted for clarity).

The scope examination of the Pd-mediated ringexpansion of VDCP disclosed a good tolerance to various carboxylic acids (Table 7). A wide range of oxabicyclo[3.2.1] oct-2-enes were prepared with low to good yields as a function of the nature of the carboxylic acid. Sterically hindered or strong acids such pivalic acid of trifluoroacetic acid led to low yields (entries 3 and 4). With glycine, a protection of the amine function was necessary to form the corresponding oxabicyclo[3.2.1]oct-2-ene compound (entries 7 and 8). Otherwise, the ring-expansion is compatible with functional groups such as halide, ether, C-C double bonds as well as heterocycles or phenol derivatives. The unique case were the endodiastereomer was detected was with cinnamic acid yet in minute amounts (entry 10).

Compared to carboxylic acids, thioacetic acid exhibited a totally different reactivity with the formation of the vinylthioester 13aa as a 2.3:1 mixture of diastereomers (Scheme 4). Interestingly, no catalyst was required and the consumption of VDCP 6aa was much faster. The structure of 13aa determined by single-crystal $\mathrm{X}$-ray analysis confirmed the addition of thioacetic acid on the diagonal carbon atom of the allene moiety. This transformation proceeds probably according to a radical process and is related to the thiophenol addition to VDCPs described by Crombie and Pattenden in 1982. ${ }^{[20]}$
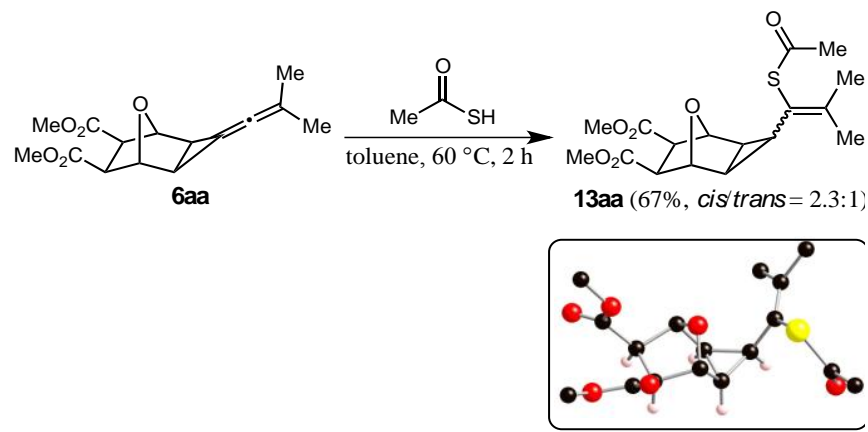

Scheme 4. Reaction of VDCP with thioacetic acid and ball-and-stick representation of compound 13aa (most of hydrogen atoms have been omitted for clarity).

To further examine the scope of the palladiumcatalyzed ring-expansion, several functionalized VDCPs 6 were tested with acetic acid (Table 8). As good to almost quantitative yields were obtained with carbonate-, ether-, silyl ether-, nitrile or carbamatesubstituted VDCPs, we believe this transformation does not present issues of functional groups compatibility.

Finally, we tackled the oxa bridge opening. Whereas numerous methods are described for ringopening reactions of $[2.2 .1]$ oxabicycles, ${ }^{[21]}$ for [3.2.1] oxabicycles the ring-opening is much more challenging. ${ }^{[15,22]}$ Following Föhilsch ${ }^{[22 \mathrm{~d}]}$ and Mascareñas ${ }^{[22 g, j]}$ procedure, we treated ester 11ea with sodium naphthalenide in THF at room temperature and mainly reduction into alcohol 14ea

Table 8.Scope of the Pd-mediated ring-expansion with various VDCPs. ${ }^{[\mathrm{a}]}$

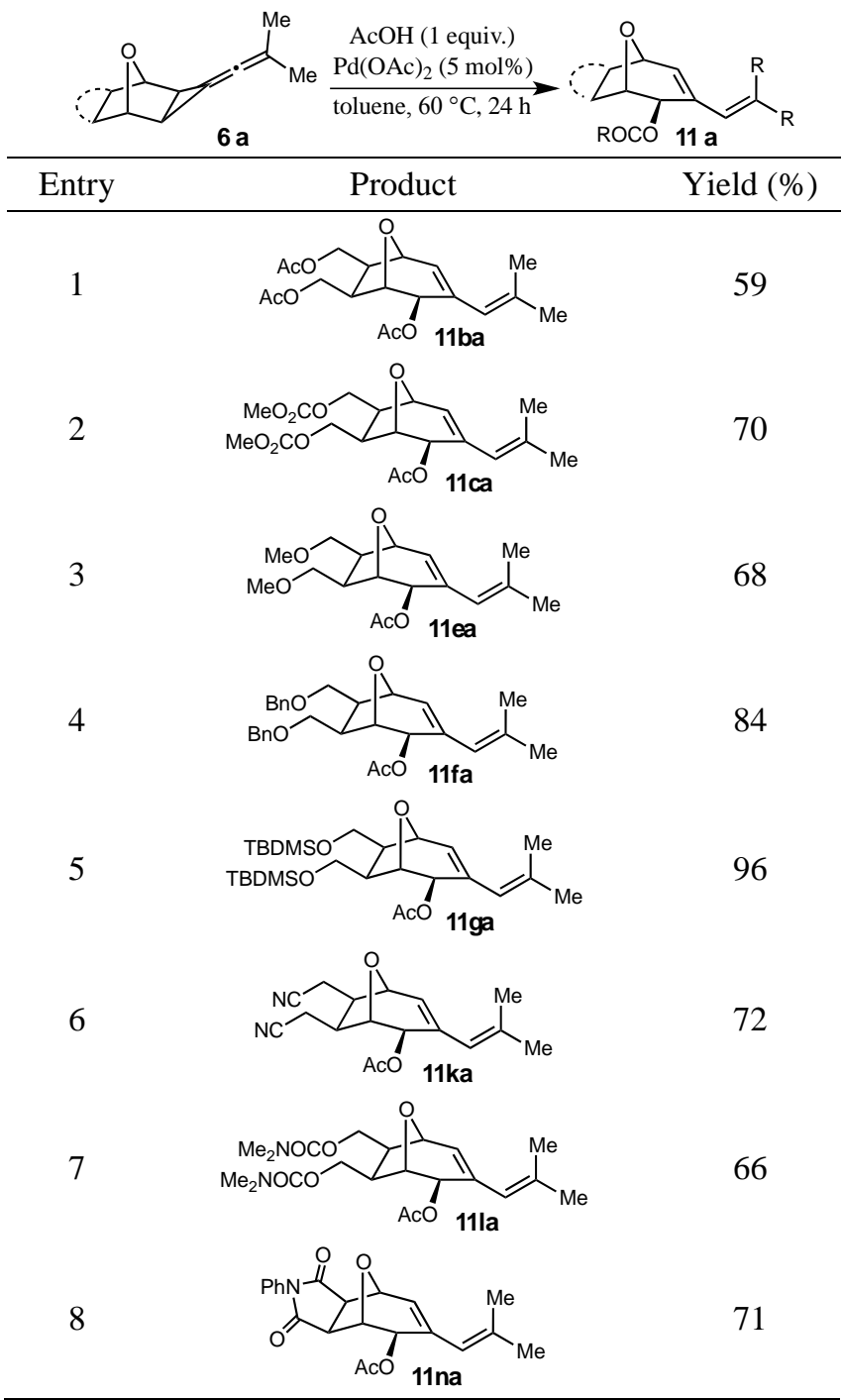

[a] Standard reaction conditions: 6aa $(0.5 \mathrm{mmol}), \mathrm{AcOH}$ $(0.5 \mathrm{mmol}), \mathrm{Pd}(\mathrm{OAc})_{2}(5 \mathrm{~mol} \%)$, toluene $(0.5 \mathrm{~mL}, 1 \mathrm{M})$, $60{ }^{\circ} \mathrm{C}, 24 \mathrm{~h}$. [b]exo/endo $=3.5: 1$.

was observed (Scheme 5). However, as a by-product, ketone 16ea was isolated in $21 \%$ yield. A control experiment showed that alcohol 14ea is not an intermediate for the ketone formation. With silyl ether 15ea, the sodium naphthalenide-mediated reductive cleavage of the oxa bridge gave a satisfactory yield of $76 \%$ in ketone $\mathbf{1 6 e a}$. 
Table 7.Pd-mediated ring-expansion with various carboxylic acid. ${ }^{[\mathrm{a}]}$

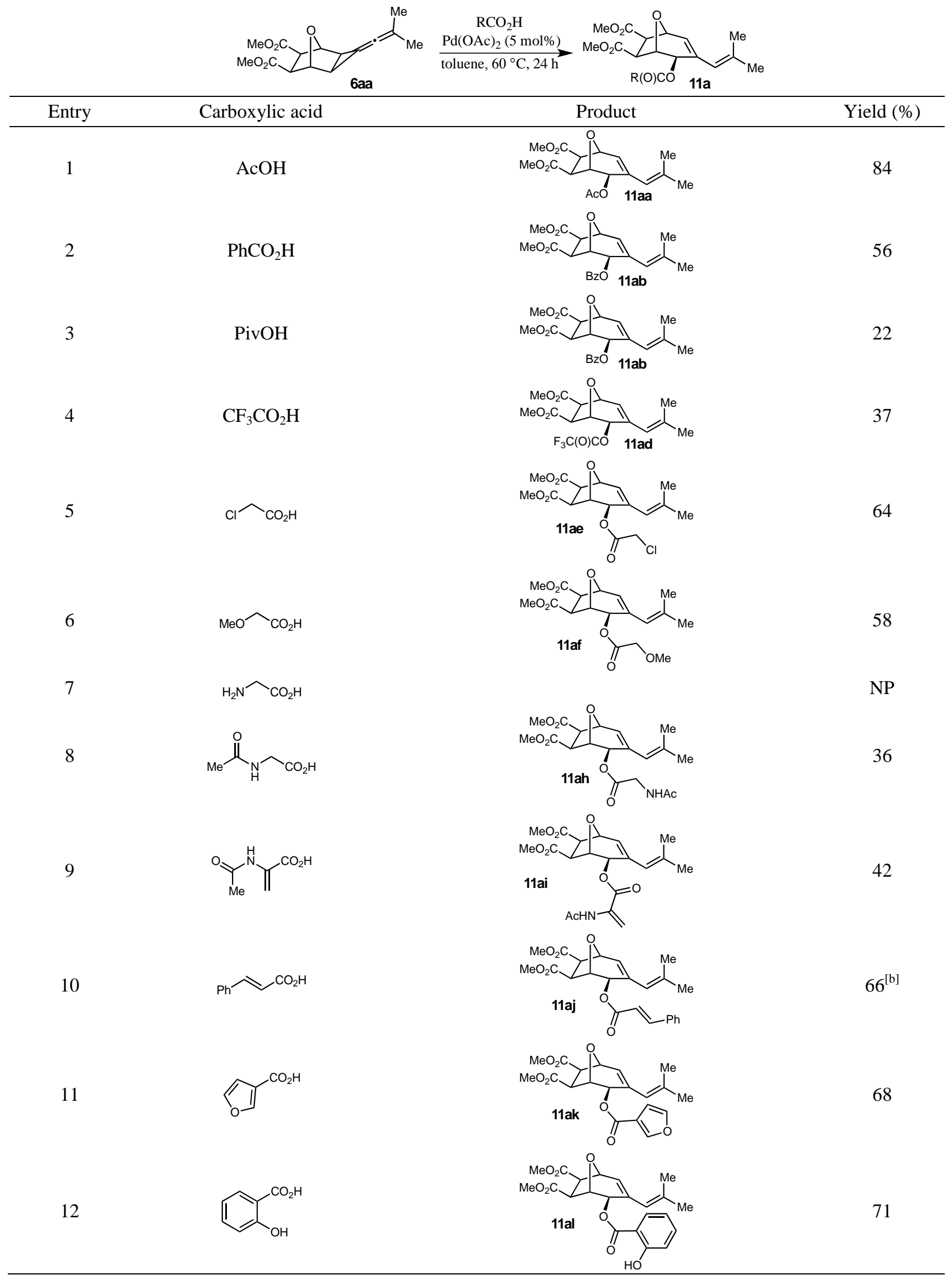

[a] Standard reaction conditions: 6aa $(0.5 \mathrm{mmol}), \mathrm{RCO}_{2} \mathrm{H}(0.5 \mathrm{mmol}), \mathrm{Pd}(\mathrm{OAc})_{2}(5 \mathrm{~mol} \%)$, toluene $(0.5 \mathrm{~mL}, 1 \mathrm{M}), 60{ }^{\circ} \mathrm{C}$, 24 h. [b]exolendo $=9: 1$. NP $=$ No Product. 


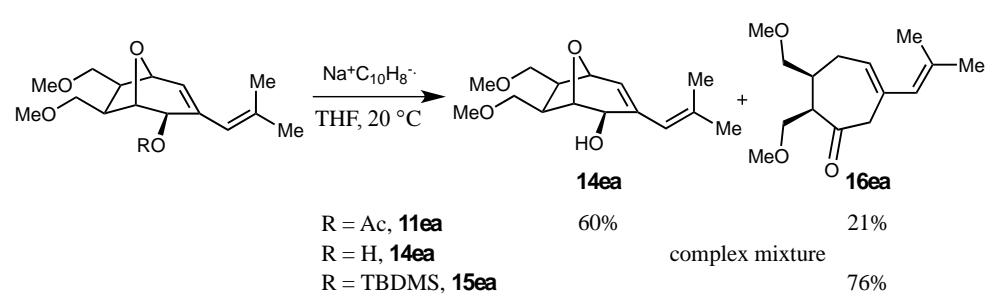

Scheme 5.Reductive cleavage of the oxa bridge.

Moreover, as depicted in Scheme 6, in situ generated nickel hydride from $\mathrm{Ni}(\mathrm{acac})_{2}$ and magnesium ethyl bromide, were efficient to ring-open the oxa bridge with concomitant isomerization of the dienic system. To our delight, diol 17fa containing 4 contiguous stereocenters was isolated in $43 \%$ yield.

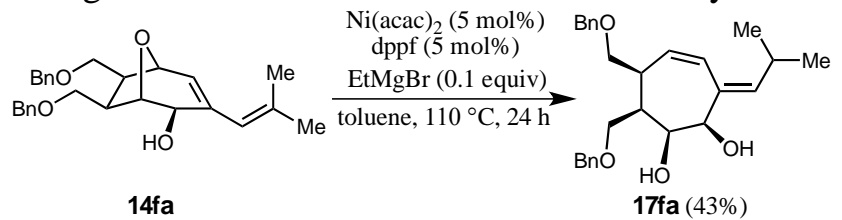

Scheme 6.Nickel-hydride mediated reductive cleavage of the oxa bridge.

\section{Conclusion}

In summary, we developed a new strategy giving access to highly functionalized 7-carbocycles using palladium-mediated catalyses and simple raw substrates. First a $[2+1]$ cycloaddition between oxanorbornenes and tertiary propargyl esters or carbonates mediated by a phosphinito-phophinous acid palladium complex afforded VDCPs $\mathbf{6}$ with high yields. It was demonstrated that this transformation is specific to the phosphinito-phophinous acid ligand and is compatible with numerous functional groups. Then, we achieved a diastereoselective palladiumcatalyzed ring-expansion with various carboxylic acids giving rise to [3.2.1] oxabicycles 11. Finally, the oxa bridge was cleaved either under reductive conditions or by nickel hydride species to afford 7membered carbocycles. Further studies on the reactivity of VDCPs and more precisely mechanistic investigations on palladium-mediated ring-expansion are currently undergoing in our laboratory.

\section{Experimental Section}

General considerations.Unless otherwise stated, all reactions were carried out in an atmosphere of dry nitrogen or argon using oven-dried $\left(120^{\circ} \mathrm{C}\right)$ glasswares. All reagents were obtained from commercial sources and used as received. SPO preligands were obtained from a chemical supplier or by following literature procedures. ${ }^{[7 a]}$ Solvents (THF, DCM, Et ${ }_{2} \mathrm{O}$ and toluene) were purified and dried over Braun solvent purification system (MB-SPS800). Analytical Thin Layer Chromatography (TLC) was carried out on Merck silica gel60 $\mathrm{F}_{254}$. Products were revealed by ultraviolet light ( 254 or $366 \mathrm{~nm}$ ) and stained with dyeing reagents solutions such as $5 \%$ phosphomolybdic acid solution, potassium permanganate solution or $p$-anisaldehyde solution in ethanol followed by gentle heating. Flash chromatography purifications were performed on Combiflash $\AA$ Companion or with Merck silica gel 60 (230-400 mesh). ${ }^{1} \mathrm{H},{ }^{13} \mathrm{C}$ and ${ }^{31} \mathrm{P}$ NMR spectra were recorded in $\mathrm{CDCl}_{3}$ at ambient temperature on Bruker Avance III 300 or 400 spectrometers operating at 300 and $400 \mathrm{MHz}$ respectively for ${ }^{\mathrm{H}} \mathrm{H}$. Solvent residual signals were used as internal standard. ${ }^{23}$ Chemical shifts $(\delta)$ and coupling constants $(J)$ are given in $\mathrm{ppm}$ and $\mathrm{Hz}$ respectively. The peaks patterns are indicated as the following format multiplicity (s: singlet; d: doublet; t: triplet; q: quartet; sept: septuplet; m: multiplet; dd: doublet of doublet; dt: doublet of triplet; etc.). The prefix br. indicates a broadened signal. HRMS were recorded on SYNAPT G2 HDMS (Waters) or on QStar Elite (Applied Biosystems SGIEX) equipped with an Atmospheric Pressure Ionization (API) source. Mass spectra were obtained a Time Of Flight (TOF) analyser. Intensity data were collected on a Brucker-Nonius KappaCCD diffractometer using graphite monochormated MoK $\alpha$ radiation $(0.71073$ A) at 293(2) K. The collected frames were processed with the software HKL-2000, structures were resolved by the direct methods and refined using the SHELXL-97 software package. ${ }^{[24]}$ The CIF files of compounds 6aa, 9aa, 11aa and 13aa have also been deposited with the CCDC as, respectively, No. CCDC 1414754 - 1414757 .

General procedure A: palladium-catalyzed [2+1] cycloaddition - formation of vinylidenecyclopropane 6. .In a $5 \mathrm{~mL}$ flame-dried Schlenk, Pd(OAc) $2(11.2 \mathrm{mg}, 0.05$ $\mathrm{mmol}, 5 \mathrm{~mol} \%)$ and $\mathrm{CyPhP}(\mathrm{O}) \mathrm{H}(26.0 \mathrm{mg}, 0.125 \mathrm{mmol}$, $12.5 \mathrm{~mol} \%$ ) were introduced under argon and dissolved in dry and degassed toluene $(2 \mathrm{~mL})$. The resulting orange solution was stirred at $60^{\circ} \mathrm{C}$ during 30 min until the orange color disappears. Then, oxanorbornene 5 ( $1 \mathrm{mmol}, 1$ equiv.), alkyne 2 ( $3 \mathrm{mmol}, 3$ equiv.) and $3 \mathrm{~mL}$ of dry and degassed toluene were added. The resulting mixture was stirred at $60^{\circ} \mathrm{C}$ for $24 \mathrm{~h}$. Then, volatiles were removed under reduced pressure. The crude mixture was purified by flash chromatography on silica gel to obtain the desired product6.

General procedure B: palladium-catalyzed ring expansion giving rise to oxabicyclo[3.2.1] oct-2-ene 11. In a $5 \mathrm{~mL}$ flame-dried Schlenk, were introduced in turn under argon, $\mathrm{Pd}(\mathrm{OAc})_{2} \quad(5.6 \mathrm{mg}, \quad 0.025 \mathrm{mmol}, 5 \mathrm{~mol} \%)$, vinylidenecyclopropane $(0.5 \mathrm{mmol})$, carboxylic acid $(0.5$ mmol, 1 equiv.) and dry toluene $(0.5 \mathrm{~mL})$. The resulting orange solution was stirred at $60^{\circ} \mathrm{C}$ for $24 \mathrm{~h}$. Then, volatiles were removed under reduced pressure. The crude mixture was purified by flash chromatography on silica gel to obtain the desired product $\mathbf{1 1}$.

(士)-6,7-bis(methoxymethyl)-3-(2-methylprop-1-en-1-

yl)cyclohept-3-enone16ea. To a solution of compound 15ea $(125 \mathrm{mg}, 0.47 \mathrm{mmol})$ in dry. THF $(5 \mathrm{~mL})$, sodium naphthalenide (prepared by stirring overnight at RT naphthalene $(640 \mathrm{mg})$ and sodium $(230 \mathrm{mg})$ in dry THF $(10 \mathrm{~mL}))$, was added until the green color persisted. Then, the reaction mixture was stirred $15 \mathrm{~min}$ at $\mathrm{rt}$ and quenched with a saturated solution of $\mathrm{NaHCO}_{3}$. The product was extracted with DCM and the organic phase was washed with brine, dried over $\mathrm{MgSO}_{4}$, and concentrated to dryness. The product was purified bycolumnchromatographyonsilicagel to afford 16ea as a colorless oil $(88 \mathrm{mg}, 76 \%$ yield $) .{ }^{1} \mathrm{H}$ NMR $(400 \mathrm{MHz}$, $\left.\mathrm{CDCl}_{3}\right): \delta=5.59\left(\mathrm{t}, J(\mathrm{H}, \mathrm{H})=6.8 \mathrm{~Hz}, 1 \mathrm{H}, \mathrm{C}=\mathrm{CH}-\mathrm{CH}_{2}\right)$, $5.53\left(\mathrm{~s}, 1 \mathrm{H}, \mathrm{CH}=\mathrm{C}\left(\mathrm{CH}_{3}\right)_{2}\right), 3.64(\mathrm{dd}, J(\mathrm{H}, \mathrm{H})=9.5$ and 7.8 $\left.\mathrm{Hz}, 1 \mathrm{H}, \mathrm{CH}_{2}-\mathrm{OMe}\right), 3.34(\mathrm{dd}, J(\mathrm{H}, \mathrm{H})=9.5$ and $5.8 \mathrm{~Hz}, 1 \mathrm{H}$, $\mathrm{CH}_{2}$-OMe), 3.27 (s, 3H, CH 3 -O), 3.20 (s, 3H, $\left.\mathrm{CH}_{3}-\mathrm{O}\right)$, $3.19-3.16\left(\mathrm{~m}, 3 \mathrm{H}, \mathrm{CH}_{2}-\mathrm{OMe}\right.$ and $\left.\mathrm{CH}_{2}-\mathrm{CO}\right), 3.06$ (dd, $J(\mathrm{H}, \mathrm{H})=9.4$ and $7.6 \mathrm{~Hz}, 1 \mathrm{H}, \mathrm{CH}-\mathrm{CO}), 3.00(\mathrm{~d}, J(\mathrm{H}, \mathrm{H})=$ $\left.16.1 \mathrm{~Hz}, 1 \mathrm{H}, \mathrm{CH}_{2}-\mathrm{CO}\right), 2.49-2.41$ (m, $\left.1 \mathrm{H}, \mathrm{CH}-\mathrm{CH}-\mathrm{CO}\right)$, $2.35-2.28(\mathrm{~m}, 1 \mathrm{H}, \mathrm{CH}-\mathrm{CH}=\mathrm{C}), 2.21-2.13\left(\mathrm{~m}, 1 \mathrm{H}, \mathrm{CH}_{2}\right.$ $\mathrm{CH}=\mathrm{C}), 1.67\left(\mathrm{~d}, J(\mathrm{H}, \mathrm{H})=1.4 \mathrm{~Hz}, 3 \mathrm{H}, \mathrm{C}-\mathrm{CH}_{3}\right), 1.66(\mathrm{~d}$, $\left.J(\mathrm{H}, \mathrm{H})=1.4 \mathrm{~Hz}, 3 \mathrm{H}, \mathrm{C}-\mathrm{CH}_{3}\right) .{ }^{13} \mathrm{C}$ NMR $(100 \mathrm{MHz}$, $\left.\mathrm{CDCl}_{3}\right): \delta=208.3(C \mathrm{O}), 134.3(C), 134.1(C), 126.83$ 
$(\mathrm{CH}), 126.80(\mathrm{CH}), 72.9\left(\mathrm{CH}_{2}\right), 70.0\left(\mathrm{CH}_{2}\right), 58.9\left(\mathrm{CH}_{3}\right)$, $58.8\left(\mathrm{CH}_{3}\right), 53.5(\mathrm{CH}), 48.8\left(\mathrm{CH}_{2}\right), 38.6(\mathrm{CH}), 29.2\left(\mathrm{CH}_{2}\right)$, $26.5\left(\mathrm{CH}_{3}\right), 19.5\left(\mathrm{CH}_{3}\right)$.HRMS (ESI): $\mathrm{m} / \mathrm{z}$ : calcd for $\mathrm{C}_{15} \mathrm{H}_{24} \mathrm{NaO}_{3}: 275.1618[\mathrm{M}+\mathrm{Na}]^{+}$; found 275.1616 .

( \pm )-(1S,2R,6S,7R,E)-6,7-bis((benzyloxy)methyl)-3-(2methylpropylidene)cyclohept-4-ene-1,2-diol17fa. To a solution of $\mathrm{Ni}(\mathrm{acac})_{2}(6.5 \mathrm{mg}, 0.025 \mathrm{mmol}, 5 \mathrm{~mol} \%)$ and dppf (13.6 mg, $0.025 \mathrm{mmol}, 5 \mathrm{~mol} \%$ ) in toluene $10 \mathrm{~mL}$, EtMgBr $1 \mathrm{M}$ in THF $(50 \mu \mathrm{L}, 0.05 \mathrm{mmol}, 0.1$ equiv.) was added at RT. After $30 \mathrm{~min}$, alcohol 14fa $(210 \mathrm{mg}, 0.5$ $\mathrm{mmol}$ ) was added and the reaction mixture was stirred $16 \mathrm{~h}$ at $110^{\circ} \mathrm{C}$. The reaction was quenched with a saturated solution of $\mathrm{NaHCO}_{3}$. The product was extracted with $\mathrm{Et}_{2} \mathrm{O}$ and the organic phase was washed with brine, dried over $\mathrm{MgSO}_{4}$, and concentrated to dryness. The product was purified bycolumnchromatographyonsilicagel to afford $17 f a$ as a yellow oil. (90 mg, 43\%) ${ }^{1} \mathrm{H}$ NMR (400 MHz, $\left.\mathrm{CDCl}_{3}\right): \delta=7.28-7.18\left(\mathrm{~m}, 10 \mathrm{H}, H^{\mathrm{Ar}}\right), 6.17(\mathrm{dt}, J(\mathrm{H}, \mathrm{H})=$ 11.7 and $2.0 \mathrm{~Hz}, 1 \mathrm{H}, \mathrm{CH}=\mathrm{CH}-\mathrm{C}=\mathrm{CH}), 5.44(\mathrm{dd}, J(\mathrm{H}, \mathrm{H})=$ 11.7 and $1.1 \mathrm{~Hz}, 1 \mathrm{H}, \mathrm{CH}=\mathrm{CH}-\mathrm{C}=\mathrm{CH}), 5.38(\mathrm{~d}, J(\mathrm{H}, \mathrm{H})=$ $9.6 \mathrm{~Hz}, 1 \mathrm{H}, \mathrm{C}=\mathrm{C} H), 4.43\left(\mathrm{~d}, J(\mathrm{H}, \mathrm{H})=4.4 \mathrm{~Hz}, 2 \mathrm{H}, \mathrm{CH}_{2-}\right.$ $\mathrm{Ph}), 4.36\left(\mathrm{~d}, J(\mathrm{H}, \mathrm{H})=7.7 \mathrm{~Hz}, 2 \mathrm{H}, \mathrm{CH}_{2}-\mathrm{Ph}\right), 4.15(\mathrm{dd}$, $J(\mathrm{H}, \mathrm{H})=8.1$ and $3.7 \mathrm{~Hz}, 1 \mathrm{H}, \mathrm{CH}=\mathrm{C}-\mathrm{CH}-\mathrm{OH}), 3.96-3.92$ $(\mathrm{m}, 1 \mathrm{H}, \mathrm{CH}=\mathrm{C}-\mathrm{CH}(\mathrm{OH})-\mathrm{CH}-\mathrm{OH}), 3.73(\mathrm{~d}, J(\mathrm{H}, \mathrm{H})=7.7$ $\mathrm{Hz}, 1 \mathrm{H}, \mathrm{CH}-\mathrm{OH}), 3.68(\mathrm{dd}, J(\mathrm{H}, \mathrm{H})=9.6$ and $7.4 \mathrm{~Hz}, 1 \mathrm{H}$, $\left.\mathrm{CH}_{2}-\mathrm{OBn}\right), 3.50-3.44\left(\mathrm{~m}, 2 \mathrm{H}, \mathrm{CH}_{2}-\mathrm{OBn}\right), 3.39(\mathrm{dd}, J(\mathrm{H}, \mathrm{H})$ $=9.4$ and $\left.6.7 \mathrm{~Hz}, 1 \mathrm{H}, \mathrm{CH}_{2}-\mathrm{OBn}\right), 3.19(\mathrm{~d}, J(\mathrm{H}, \mathrm{H})=8.3 \mathrm{~Hz}$, $1 \mathrm{H}, \mathrm{CH}-\mathrm{OH}), 2.69-2.65\left(\mathrm{~m}, 1 \mathrm{H}, \mathrm{CH}-\mathrm{CH}_{2}-\mathrm{OBn}\right), 2.52-2.44$ $\left(\mathrm{m}, 2 \mathrm{H}, \mathrm{CH}-\mathrm{CH}_{2}-\mathrm{OBn}\right.$ and $\left.\mathrm{CH}\left(\mathrm{CH}_{3}\right)_{2}\right), 0.88(\mathrm{dd}, J(\mathrm{H}, \mathrm{H})=$ 6.7 and $\left.1.2 \mathrm{~Hz}, 6 \mathrm{H}, \mathrm{CH}_{3}\right) .{ }^{13} \mathrm{C} \mathrm{NMR}\left(100 \mathrm{MHz} \mathrm{CDCl}_{3}\right): \delta$ $=138.6(C \mathrm{H}), 137.7(C), 137.6(C), 133.5(C), 130.6(C \mathrm{H})$, $128.48 \quad(C \mathrm{H}), 128.46 \quad(\mathrm{CH}), 127.85 \quad(\mathrm{CH}), 127.81$ $(\mathrm{CH}), 127.79(\mathrm{CH}), 127.73(\mathrm{CH}), 127.70(\mathrm{CH}), 127.0(\mathrm{CH})$, 76.7 $(\mathrm{CH}), 75.1(\mathrm{CH}), 73.4\left(\mathrm{CH}_{2}\right), 73.3\left(\mathrm{CH}_{2}\right), 70.9\left(\mathrm{CH}_{2}\right)$, $69.3\left(\mathrm{CH}_{2}\right), 41.4(\mathrm{CH}), 38.9(\mathrm{CH}), 27.3(\mathrm{CH}), 22.8\left(\mathrm{CH}_{3}\right)$, $22.6\left(\mathrm{CH}_{3}\right) . \mathrm{HRMS}$ (ESI): $\mathrm{m} / z$ : calcd for $\mathrm{C}_{27} \mathrm{H}_{34} \mathrm{NaO}_{4}$ : $445.2349[\mathrm{M}+\mathrm{Na}]^{+}$; found 445.2352 .

\section{Acknowledgements}

This work was supported by the Ministère de l'enseignement supérieur et de la recherche (A.L. Ph.D. grant), CNRS, ECM, AMU and ANR (project BLAN07-1_190839 SPOs Preligands). We thank Christophe Chendo and Dr. Valérie Monnier for mass spectrometry analyses and Dr. Michel Giorgi for X-ray determination (Spectropole, Fédération des Sciences Chimiques de Marseille).

\section{References}

[1] a) L. Yet, Chem. Rev.2000, 100, 2963-3007; b) I. V. Hartung, M. R. Hoffmann, Angew. Chem.2004, 116, 1968-1984; Angew. Chem. Int. Ed.2004, 43, 19341949; c) M. B. Fraga, Nat. Prod. Rep.2005, 22, 465486; d) T. V. Nguyen, J. M. Hartmann, D. Enders, Synthesis2013, 45, 845-873; e) G. Buono, H. Clavier, L. Giordano, A. Tenaglia in Stereoselective multiple bond-forming transformations in organic synthesis (Eds.: J. Rodriguez, D. Bonne), Wiley, Hoboken, 2015, pp. 211-240.

[2] M. A. Battiste, P. M. Pelphrey, D. L. Wright, Chem. Eur. J. 2006, 12, 3438-3447.

[3] H. Butenschön, Angew. Chem.2008, 120, 5367-5370; Angew. Chem. Int. Ed.2008, 47, 5287-5290.

[4] a) M. Harmata, Chem. Commun. 2010, 46, 8886-8903; b) M. Harmata, Chem. Commun.2010, 46, 8904-8922; c) A. G. Lohse, R. P. Hsung, Chem. Eur. J.2011, 17, 3812-3822.

[5] a) H. Pellissier, Adv. Synth. Catal.2011, 353, 189-218; b) K. E. O. Ylijoki, J. M. Stryker, Chem. Rev.2013, 113, 2244-2266; c) H. Clavier, H. Pellisier in Methods and Applications of Cycloaddition Reactions in Organic Syntheses (Ed.: N. Nishiwaki), Wiley, Hoboken, 2014, pp. 631-654.

[6] For reviews on secondary phosphine oxides, see: a) L. Ackermann, Synthesis2006, 1557-1571; b) L. Ackermann, R. Born, J. H. Spatz, A. Althammer, C. J. Gschrei, Pure Appl. Chem.2006, 78, 209-214; c) L. Ackermann, Synlett2007, 507-526; d) L. Ackermann In Phosphorus Ligands in Asymmetric Catalysis, Vol. 2 (Ed.: A. Börner), Wiley-VCH, Weinheim, 2008, pp. 831-847; e) T. M. Shaikh, C.-M. Weng, F.-E. Hong, Coord. Chem. Rev.2012, 256, 771-803.

[7] a) T. Achard, L. Giordano, A. Tenaglia, Y. Gimbert, G. Buono, Organometallics 2010, 29, 3936-3950; b) D. Martin, D. Moraleda, T. Achard, L. Giordano, G. Buono, Chem. Eur. J.2011, 17, 12729-12740; c) L. V. Graux, M. Giorgi, G. Buono, H. Clavier, Organometallics 2015, 34, 1864-1871.

[8] a) J. Bigeault, L. Giordano, G. Buono, Angew. Chem.2005, 117, 4831-4835; Angew. Chem. Int. Ed.2005, 44, 4753-4757; b) J. Bigeault, L. Giordano, I. De Riggi, Y. Gimbert, G. Buono, Org. Lett.2007, 9, 3567-3570; c) T. Achard, A. Lepronier, Y. Gimbert, H. Clavier, L. Giordano, A. Tenaglia, G. Buono, Angew. Chem. 2011, 123, 3614-3618; Angew. Chem. Int. Ed.2011, 50, 3352-3356; d) H. Clavier, A. Lepronier, N. Bengobesse-Mintsa, D. Gatineau, H. Pellissier, L. Giordano, A. Tenaglia, G. Buono, Adv. Synth. Catal.2013, 355, 403-408.

[9] J. Bigeault, I. De Riggi, Y. Gimbert, L. Giordano, G. Buono, Synlett2008, 1071-1075.

[10] For reviews on vinylidenecyclopropanes, see: a) J.-M. Lu, M. Shi, Tetrahedron2006, 62, 9115-9122; b) M. Shi, L.-X. Shao, J.-M. Lu, Y. Wei, K. Mizuno, H. Maeda, Chem. Rev.2010, 110, 5883-5913; c) D.-H. Zhang, X.-Y. Tang, M. Shi, Acc. Chem. Res.2014, 47, 913-924; For an interesting paper on the reactivity of VDCP, see: G.-C. Xu, L.-P. Liu, J.-M. Lu, M. Shi, J
Am. Chem. Soc.2005, 127, 14552-14553.

[11] For selected publications on ring expansion of bicyclo[4.1.0]heptanes, see: a) Y. Ito, S. Fujii, T. Saegusa, T. J. Org. Chem.1976, 41, 2073-2074; b) D. A. Evans, D. J. Hart, P. M. Koelsch, J. Am. Chem. Soc.1981, 103, 5813-5821; c) H. B. Lee, M. J. Sung, S. C. Blackstock, J. K. Cha, J J. Am. Chem. Soc.2001, 123, 11322-11324; d) S. Chiba, M. Kitamura, K. Narasaka, J. Am. Chem. Soc.2006, 128, 6931-6937; e) J. Jiao, L. X. Nguyen, D. R. Patterson, R. A. Flowers II, Org. Lett.2007, 9, 1323-1326; f) H. Tsuchida, M. Tamura, E. Hasegawa, J. Org. Chem.2009, 74, $2467-$ 2475 ; g) Y.-F. Wang, K. K. Toh, E. P. J. Ng, S. Chiba, J. Am. Chem. Soc.2011, 133, 6411-6421; h) M.-C. P. Yeh, C. J. Liang, C. W. Fan, W. H. Chiu, J. Y. Lo, J. Org. Chem.2012, 77, 9707-9717; 
[12] a) G.-C. Xu, M. Ma, L.-P. Liu, M. Shi, Synlett2005, 1869-1872; b) X. Huang, C. Su, Q. Liu, Y. Song, Synlett, 2008, 229-232; c) C. Su, X. Huang, Adv. Synth. Catal.2009, 351, 135-140; d) C. Su, X. Huang, Q. Liu, X. Huang, J. Org. Chem.2009; 74, 8272-8279.

[13] M. Presset, Y. Coquerel, K. Rodriguez, Chem. Rev.2013, 113, 525-595.

[14] a) R.E. Moore in Marine Natural Products: Chemical and Biological Perspectives, Vol. 2 (Ed.P.J. Scheuer), Academic, New York, 1978; b) K. C. Nicolaou, J. S. Chen, Pure Appl. Chem.2008, 80, 727-742; c) G. Majetich, J. Yu, Org. Lett.2008, 10, 89-91; d) K. Tiefenbacher, J. Mulzer, Angew. Chem.2008, 120, 2582-2590; Angew. Chem. Int. Ed.2008, 47, 25482555;e) E. Jimenez-Nunez, K. Molawi, A. M. Echavarren, Chem. Commun.2009, 7327-7329; f) K. Palanichamy, K. P. Kaliappan, Chem. Asian J.2010, 5, 668-703; g) N. Hardin, R. Alison, E. M. Simmons, R. Sarpong, Eur. J. Org. Chem.2010, 3553-3567; h) D. Y.-K. Chen; C.-C. Tseng, Org. Biomol. Chem.2010, 8, 2900-2911; i) M. Saleem, H. Hussain, I. Ahmed, T. van Ree, K. Krohn, Nat. Prod. Rep.2011, 28, 15341579; j) W. J. Chain, Synlett2011, 18, 2605-2608; k) A. Padwa, Tetrahedron2011, 67, 8057-8072; 1) R. H. Pouwer, J.-A. Richard, C.-C. Tseng, D. Y.-K. Chen, Chem. Asian J.2012, 7, 22-35; m) J. Wang, S.-G. Chen, B.-F. Sun, G.-Q. Lin, Y.-J. Shang, Chem. Eur. J.2013, 19, 2539-2547; n) M. Flores, D. Perez, Synlett, 2014, $25,1643-1666$.

[15] S. Goudedranche, D. Pierrot, T. Constantieux, D. Bonne, J. Rodriguez, Chem. Commun.2014, 50, 1560515608.

[16] P. Nava, H. Clavier, Y. Gimbert, L. Giordano, G. Buono, S Humbel, ChemCatChem, in press, DOI: 10.1002/cctc.201500809.

[17] a) E. L. Eliel, S. H. Wilen, L. N. Mander, in Stereochemistry of Organic Compounds, Wiley: New York, 1994, pp. 1137-1138; b) R. E. Lyle, G. G. Lyle, J. Org. Chem. 1957, 22, 856; c) R. E. Lyle, G. G. Lyle, J. Org. Chem. 1959, 24, 1679-1684; d) G. G. Lyle, E. T. Pelosi, J. Am. Chem. Soc. 1966, 88, 5976-5279.

[18] For recent examples, see: a) S. Chandrasekhar, S. K. Gorla, Tetrahedron: Asymmetry2006, 17, 92-98; b) D. Gatineau, D. Moraleda, J.-V. Naubron, T. Bürgi, L. Giordano, G. Buono, Tetrahedron: Asymmetry2009, 20, 1912-1917; c) C. Cismas, N. Vanthuyne, H. Rispaud; R.
A. Varga, E. Bogdan, C. Roussel, I. Grosu, Chirality2011, 23, 167-171.

[19] For a related reactivity of VDCPs with acetic acid in presence of palladium, see: J.-M. Lu, M. Shi, Tetrahedron 2006, 62, 9115-9122.

[20] P. M. Cairns, L. Crombie, G. Pattenden, Tetrahedron Lett.1982, 23, 1405-1408.

[21] For reviews, see: a) P. Chiu, M. Lautens, in Topics Curr. Chem., (Ed.: P. Metz), Springer Verlag, New York, 1997, vol. 190, pp. 1-85; b) M. Lautens, K. Fagnou, S. Heibert, Acc. Chem. Res. 2003, 36, 48-58. c) R. G. Arrayás, S. Cabrera, J. C. Carretero, Synthesis2006, 1205-1219; d) D. K. Rayabarapu, C.-H. Cheng, Acc. Chem. Res.2007, 40, 971-983; e) C. S. Schindler, E. M. Carreira, Chem. Soc. Rev.2009, 38, 3222-3241.

[22] For selected references, see: a) M. Lautens, E. Fillion, M. Sampat, J. Org. Chem.1997, 62, 7080-7081; b) M. Lautens, T. Rovis, J. Am. Chem. Soc.1997, 119, 1109011091. c) J. R. Rodrgíuez, L. Castedo, J. L. Mascareñas, Synthesis2000, 980-984; d) G. Kreiselmeier, B. Föhlisch, Tetrahedron Lett.2000, 41, 1375-1379; e) J. C. Lee, J. K. Cha, J. Am. Chem. Soc.2001, 123, $3243-$ 3246; f) M. Lautens, S. Hiebert, J.-L. Renaud, J. Am. Chem. Soc.2001, 123, 6834-6839. g) F. López, L. Castedo, J. L. Mascareñas, J. Am. Chem. Soc.2002, 124, 4218-4219; h) D. Hodgson, C. R. Maxwell, T. J. Miles, E. Paruch, M. A. H. Stent, I. R. Matthews, F. X. Wilson, J. Witherington, Angew. Chem. 2002, 119, 4489-4492; Angew. Chem. Int. Ed.2002, 41, 4313-4316; i) U. M. Krishna, G. K. Trivedi, Tetrahedron Lett. 2004, 45, 257-259; j) F. López, L. Castedo, J. L. Mascareñas, Org. Lett.2005, 7, 287-290; k) D. E. Ward, J. Shen, Org. Lett.2007, 9, 2843-2846; 1) S. Xing, Y. Li, C. Liu, J. Ren, Z. Wang, Angew. Chem. 2011, 123, 12813 12817; Angew. Chem. Int. Ed.2011, 50, 12605-12609; m) Y. D. Williams, C. Meck, N. Mohd, R. P. Murelli, J. Org. Chem.2013, 78, 11707-11713; n) E. Z. Oblak, M. D. VanHeyst, J. Li, A. J. Wiemer, D. L. Wright, J. Am. Chem. Soc. 2014, 136, 4309-4315.

[23] G. R. Fulmer, A. J. M.Miller,N. H. Sherden,H. E. Gottlieb, A.Nudelman, B. M. Stoltz,J. E. Bercaw, K. I. Golberg, Organometallics 2010, 29, 2176-2179.

[24] G. M. Shelcrick, Acta Cryst.2008, A64, 112-122. 


\section{FULL PAPER}

Palladium-catalyzed [2+1] cycloadditions affording vinylidenecyclopropanes as precursors of 7-

membered carbocycles

Adv. Synth. Catal.Year, Volume, Page - Page

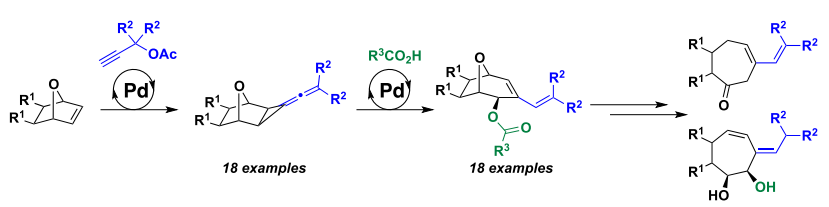

Aymeric Lepronier, Thierry Achard, Laurent

Giordano, Alphonse Tenaglia, Gérard Buono,

Hervé Clavier* 